\title{
The effect of dietary protein and energy restriction on heat production and growth costs in the young rat
}

\author{
By PENNY A. COYER, J. P. W. RIVERS AND D. J. MILLWARD \\ Nutrition Research Unit, Department of Human Nutrition, London School of Hygiene \\ and Tropical Medicine, 4 St Pancras Way, London NW1 2PE
}

(Received 21 March 1986 - Accepted 20 January 1987)

\begin{abstract}
1. The effect of dietary protein and energy restriction on heat production and growth costs has been examined in rats fed on a marginal (MP) or high (HP) protein diet, containing $9 \cdot 2 \%$ or $22 \%$ respectively of the gross energy content as casein. Diets were given either ad lib. or at approximately 25,50 or $75 \%$ of the ad lib. intake.

2. Heat production ( $\mathrm{kJ} / \mathrm{kg}$ body-weight $(\mathrm{W})^{0.75}$ per d) was increased by $23 \%$ in rats fed on the MP diet $a d l i b$., as compared with their HP controls $(P<0.01)$.

3. Factorial analysis of the data showed that the overall cost of energy deposition $(\mathrm{kJ} / \mathrm{kJ} ; \mathrm{Ee})$ was elevated on the MP diet (MP 1.7, HP 1.28; $P<0.001$ ). Maintenance requirements $\left(\mathrm{kJ} / \mathrm{kg} \mathrm{W}^{0.75}\right.$ per d) for zero energy balance were unchanged (MP 562, HP 573).

4. The partial energy cost of protein deposition (Ep) varied with dietary manipulation. If the partial energy cost of fat deposition (Ef) was assumed constant at $1.25 \mathrm{~kJ} / \mathrm{kJ}$, and maintenance requirements were assumed to vary with metabolic body size $\left(\mathrm{W}^{0 \cdot 75}\right)$, Ep was elevated on the MP diet. On both diets, Ep was reduced at low energy intakes.

5. The significance of these results is discussed in the context of current approaches to the analysis and interpretation of findings describing dietary induced changes in the rate of heat production.
\end{abstract}

The effect of dietary protein concentration on the heat production of experimental animals is a long standing controversy (Miller \& Payne, 1962; McCracken, 1975). Despite a recent resurgence of interest in the topic, no consensus of opinion has emerged. Several authors have concluded that the earlier findings of Miller \& Payne (1962) are correct, demonstrating increases in the rate of heat production and reductions in gross energetic efficiency with dietary protein restriction, in the rat (McCracken \& Gray, 1976; Tulp et al. 1979; Rothwell et al. 1982; Swick \& Gribskov, 1983) and pig (Gurr et al. 1980). By contrast, Fuller (1983) and McCracken \& McAllister (1984) concluded that their findings provided little evidence to support the concept of dietary-induced thermogenesis in response to reductions in dietary protein concentration. Several methodological and physiological explanations have been advanced to account for these incongruities (McCracken, 1975; Sawaya \& Lunn, 1985); the disparate conclusions may also reflect differences in the interpretation of essentially compatible findings.

In the context of classical factorial analysis of energy expenditure, alterations in the rate of heat production may be ascribed to changes in the maintenance requirement or to changes in growth costs. Reductions in dietary protein content usually result in a depressed protein content of tissue gain, so that in accordance with the accepted frameworks for the prediction of energy requirements (Agricultural Research Council, 1981; Food and Agriculture Organization/World Health Organization/United Nations University, 1985) the overall cost of energy deposition (Ee), should fall, since the partial energy cost of fat deposition (Ef) is generally considered to be less than the partial energy cost of protein deposition (Ep) (Kielanowski, 1976). Studies have, however, failed to show a statistically significant change in Ee with reductions in dietary protein concentration (McCracken \& Weatherup, 1973; Close et al. 1983) even where energy requirements for maintenance were increased (Walker \& Norton, 1971). Alternatively, the Ep and Ef might vary with dietary protein concentration, but conclusions are equivocal: Close et al. (1983) found that when 
Table 1. Composition of experimental diets $(\mathrm{g} / \mathrm{kg}$ dry matter)

\begin{tabular}{|c|c|c|}
\hline & High protein & Marginal protein \\
\hline \multicolumn{3}{|l|}{ Ingredients } \\
\hline Casein & $183 \cdot 4$ & $73 \cdot 4$ \\
\hline Maize starch & $500 \cdot 7$ & $586 \cdot 6$ \\
\hline Dextrose & $109 \cdot 7$ & $129 \cdot 3$ \\
\hline L-Methionine & $1 \cdot 8$ & 0.8 \\
\hline Maize oil & $50-0$ & 50 \\
\hline Vitamin mixture* & $19 \cdot 9$ & $19 \cdot 9$ \\
\hline Mineral mixture $\dagger$ & $39 \cdot 7$ & $39 \cdot 9$ \\
\hline Cellulose powder & $94 \cdot 7$ & 100 \\
\hline \multicolumn{3}{|l|}{ Analysis } \\
\hline Gross energy (MJ/kg) & $18-4$ & $17 \cdot 6$ \\
\hline Total solids $(\mathrm{g} / \mathrm{kg})$ & $920-0$ & $920 \cdot 0$ \\
\hline Nitrogen $(\mathrm{g} / \mathrm{kg})$ & $26 \cdot 6$ & $10 \cdot 8$ \\
\hline Gross energy from protein (\%) & $22 \cdot 0$ & $9 \cdot 2$ \\
\hline
\end{tabular}

* Special diet services, Witham, Essex, providing (g/ $\mathrm{kg}$, made up in dextrose): retinol 4.5, ergocalciferol 0.25 , $\alpha$-tocopherol 5 , ascorbic acid 45 , inositol 5 , choline chloride 75 , menadione $2 \cdot 25$, $p$-aminobenzoic acid 5 , nicotinic acid $4 \cdot 5$, riboflavin 1 , pyroxine hydrochloride 1 , thiamin hydrochloride 1 , calcium pantothenate 3 , biotin $20 \mathrm{mg}$, folic acid $90 \mathrm{mg}$, vitamin $B_{12} 1.35 \mathrm{mg}$.

† Bernhart-Tomarelli Salt Mixture, (ICN Nutritional Biochemicals, Cleveland, Ohio) providing ( $\mathrm{g} / \mathrm{kg}$ ): calcium carbonate 21 , calcium phosphate $\left(\mathrm{CaHPO}_{4}\right) 735$, citric acid $2 \cdot 3$, cupric citrate $0 \cdot 47$, dipotassium phosphate 81 , ferric citrate $.5 \mathrm{H}_{2} \mathrm{O} 5 \cdot 6$, magnesium oxide 25 , manganese citrate $8 \cdot 35$, potassium iodide $0 \cdot 01$, potassium sulphate 68 , sodium chloride 30 , disodium phosphate $21 \cdot 4$, zinc citrate $.2 \mathrm{H}_{2} \mathrm{O} 1 \cdot 33$.

a constant value for Ef was assumed, Ep was unchanged with reductions in dietary protein content, while Campbell \& Dunkin (1983) concluded that Ep was increased on low-protein diets.

The experiments described here were conducted to investigate the effect of dietary protein concentration on heat production and growth costs in young rats. A preliminary account of these results has already been presented (Coyer et al. 1985a).

\section{MATERIALS AND METHODS}

The animals used were male Sprague Dawley rats. Sixty weight-matched rats were obtained from the supplier (Charles River; Margate, Kent) and individually caged at $25^{\circ}(12 \mathrm{~h}$ light-12 h dark cycle). For 1 week before study, rats were fed on a synthetic diet of a highprotein content (see Table 1). At the outset of the experiment, rats were selected from the starting group on the basis of similarity in body-weight (mean weight 103.5 (s.E. 0.9) g). Due to marked variability in initial growth rate, only forty-seven rats could be used for the experiment and these were divided into nine weight-matched groups. Nine rats were killed by chloroform anaesthesia for determination of baseline carcass composition. The remaining rats were fed on either a high (HP) or marginal (MP) protein diet at four levels of food intake, for $7 \mathrm{~d}$ (see Table 2), then killed. Cages were suspended over plastic trays lined with absorbent paper, to facilitate collection of spillage and faeces. Rats were weighed daily between 08.30 and 09.30 hours.

Total food consumed was determined as the difference between the dry weight of food fed and the dry weight of spillage. The gross energy (GE) content of food and pooled faeces was determined by ballistic bomb calorimetry (Miller \& Payne, 1959) of triplicate samples. The apparent digestible energy intake (DE) was estimated as the difference between the GE content of the food eaten and the GE of the faeces. 
Table 2. Feeding schedules of experimental groups

\begin{tabular}{cccc}
\hline \hline Dietary energy level & Dietary protein level* & Amount of food given (g/d) & $n$ \\
\hline A & High & Ad lib. & 4 \\
& Marginal & Ad lib. & 4 \\
B & High & 12 & 5 \\
& Marginal & 12 & 5 \\
C & High & 8 & 5 \\
& Marginal & 8 & 5 \\
D & High & 4 & 5 \\
& Marginal & 4 & 5 \\
\hline
\end{tabular}

* For details, see Table 1.

Frozen carcasses of the day 0 and day 7 experimental rats were finely ground in a Type 320 Moulinex Chopper, freeze-dried and reground before analysis of energy and crude protein (nitrogen $\times 6.25 ; \mathrm{CP} ; \mathrm{Kjeltec}$ auto 1030 analyser) content. It was found in previous experiments that the gross energy content of freeze-dried samples of rats of approximately $110 \mathrm{~g}$ live weight could be estimated with a coefficient of variation (three samples) of $1-2 \%$. The energy and protein contents of day 0 rats (live weight) were calculated and used to estimate the baseline carcass composition in the experimental rats. Energy and protein depositions in the day 7 rats were estimated by difference from the day 0 values. Energy deposition as fat was estimated as the difference between the total energy deposition, and energy deposition as protein (assuming $23.8 \mathrm{~kJ} / \mathrm{g}$ protein). Metabolizable energy intake (MEI) was estimated from DE assuming that all nitrogen was lost as urea with an energy content of $25 \mathrm{~kJ} / \mathrm{g} \mathrm{N}$ lost (Kleiber, 1975). Heat production was calculated as the difference between MEI and energy deposition. Average body protein content during the experimental period was estimated from day 0 and day 7 carcass protein contents, assuming a linear rate of gain.

\section{Statistical analysis}

Results are presented as means with their standard errors. The statistical significances of the effects of dietary protein and energy restriction were analysed by two-way analysis of variance for non-orthogonal data in a $2 \times$ column table (Armitage, 1971). Since there were significant protein $\times$ energy interactive effects on MEI $(P<0.05)$, protein gain, heat production and weight gain $(P<0.005)$, the data were further analysed by comparing differences between means using Student's $t$ test for unpaired values (two-tailed), adjusted where necessary to account for unequal variances around the means. The data were also analysed using linear and quadratic regression analyses. The statistical significance of differences between regression coefficients was tested by Student's $t$ test for unpaired values (two-tailed), adjusted where necessary to account for unequal variances around the means (Bailey, 1981).

\section{RESULTS AND DISCUSSION}

\section{Heat production and body composition}

The results confirm that growth rate and energy retention in young rats are sensitive to both dietary protein and energy restriction. Rats fed on the MP diet to appetite consumed the same amount of food (MEI, $\mathrm{kJ} / \mathrm{d}$ ) as their ad lib. controls eating the HP diet, but gained less weight (Table 3). Heat production ( $\mathrm{kJ} / \mathrm{kg}$ body-weight $(\mathrm{W})^{0 \cdot 75}$ per $\mathrm{d}$ ) was increased on 


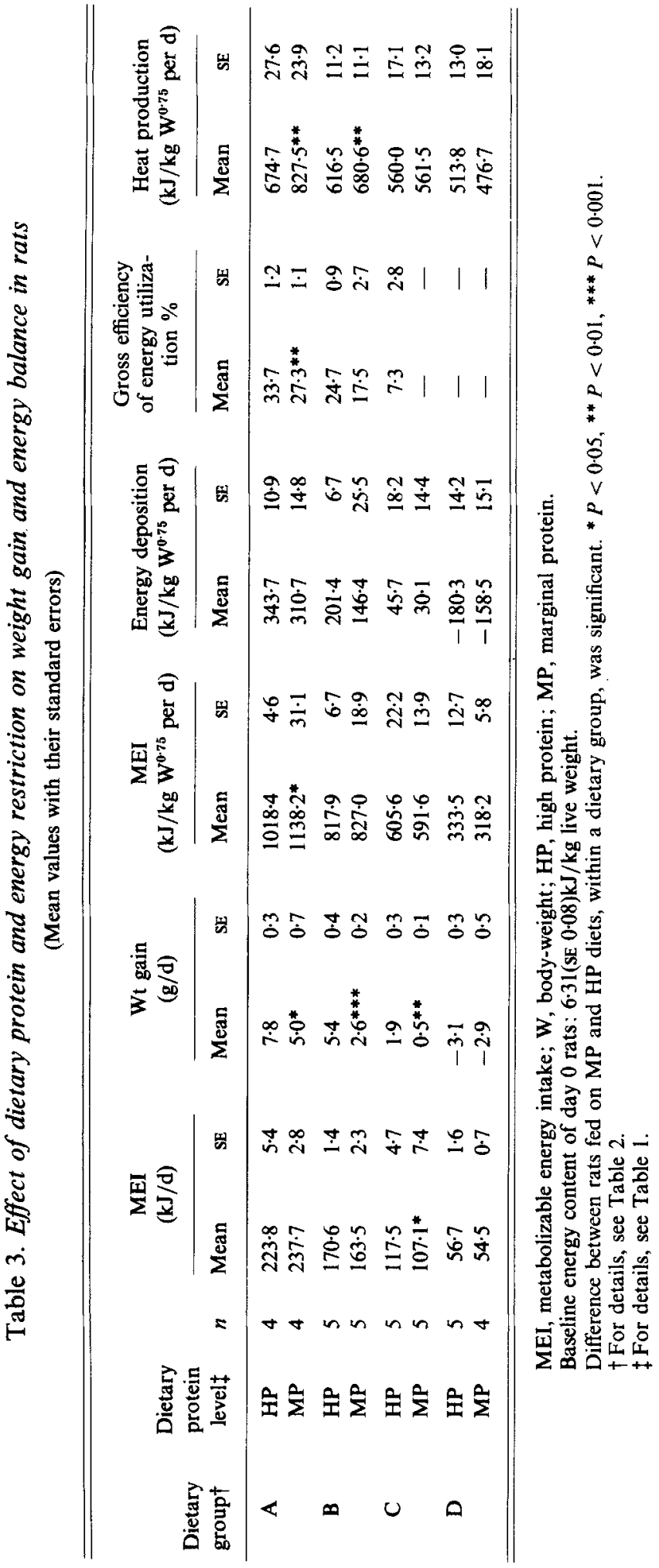


Table 4. Effect of dietary energy and protein restriction on protein and fat deposition in rats

(Mean values with their standard errors)

\begin{tabular}{|c|c|c|c|c|c|c|c|}
\hline \multirow{2}{*}{$\begin{array}{l}\text { Dietary } \\
\text { group }{ }^{\dagger}\end{array}$} & \multirow{2}{*}{$\begin{array}{l}\text { Dietary } \\
\text { protein } \\
\text { level }\end{array}$} & \multirow[b]{2}{*}{$n$} & \multirow{2}{*}{ 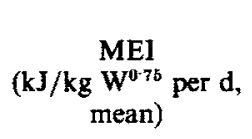 } & \multicolumn{2}{|c|}{$\begin{array}{c}\text { Protein } \\
\left(\mathrm{kJ} / \mathrm{kg} \mathrm{W}^{0.75} \text { per d) }\right.\end{array}$} & \multicolumn{2}{|c|}{$\begin{array}{c}\text { Fat } \\
\left(\mathrm{kJ} / \mathrm{kg} \mathrm{W^{0.75 }} \text { per d) }\right.\end{array}$} \\
\hline & & & & Mean & $\mathrm{SE}$ & Mean & $\mathbf{S E}$ \\
\hline $\mathbf{A}$ & $\begin{array}{l}\text { HP } \\
\text { MP }\end{array}$ & $\begin{array}{l}4 \\
4\end{array}$ & $\begin{array}{l}1018 \cdot 4 \\
1138 \cdot 2\end{array}$ & $\begin{array}{l}138 \cdot 9 \\
79 \cdot 6^{* * * *}\end{array}$ & $\begin{array}{l}4 \cdot 0 \\
2 \cdot 0\end{array}$ & $\begin{array}{l}204 \cdot 8 \\
231 \cdot 1\end{array}$ & $\begin{array}{l}11.7 \\
13.7\end{array}$ \\
\hline B & $\begin{array}{l}\text { HP } \\
\text { MP }\end{array}$ & $\begin{array}{l}5 \\
5\end{array}$ & $\begin{array}{l}817.9 \\
789.8\end{array}$ & $\begin{array}{l}123 \cdot 1 \\
44 \cdot 8^{* * *}\end{array}$ & $\begin{array}{l}2 \cdot 8 \\
5 \cdot 1\end{array}$ & $\begin{array}{r}78 \cdot 3 \\
101 \cdot 6\end{array}$ & $\begin{array}{r}5 \cdot 1 \\
22 \cdot 3\end{array}$ \\
\hline $\mathrm{C}$ & $\begin{array}{l}\text { HP } \\
\text { MP }\end{array}$ & $\begin{array}{l}5 \\
5\end{array}$ & $\begin{array}{l}605.6 \\
591.6\end{array}$ & $\begin{array}{l}74 \cdot 5^{* *} \\
8 \cdot 2\end{array}$ & $\begin{array}{l}5 \cdot 2 \\
4 \cdot 0\end{array}$ & $\begin{array}{r}-28 \cdot 8 \\
21 \cdot 8^{*}\end{array}$ & $\begin{array}{l}16 \cdot 2 \\
10 \cdot 6\end{array}$ \\
\hline D & $\begin{array}{l}\text { HP } \\
\text { MP }\end{array}$ & $\begin{array}{l}5 \\
4\end{array}$ & $\begin{array}{l}335 \cdot 5 \\
318 \cdot 2\end{array}$ & $\begin{array}{l}-61 \cdot 1 \\
-51 \cdot 4\end{array}$ & $\begin{array}{r}11 \cdot 7 \\
9 \cdot 0\end{array}$ & $\begin{array}{l}-119 \cdot 2 \\
-107 \cdot 2\end{array}$ & $\begin{array}{r}17 \cdot 4 \\
8 \cdot 3\end{array}$ \\
\hline
\end{tabular}

MEI, metabolizable energy intake; W, body-weight; HP, high protein; MP, marginal protein.

Baseline protein content of day 0 rats: 0.19 (SE 0.002)g/g live weight.

Difference between rats fed on MP or HP diets, within a dietary group, was significant; ${ }^{* *} P<0.01$, ***P $<<001$

† For details, see Table 2.

$\ddagger$ For details, see Table 1 .

the MP diet, so that gross efficiency of energy utilization was depressed compared with controls. This is consistent with other findings in this laboratory. In a recent study (Coyer et al. 1986), energy intakes were (kJ/kg W $\mathrm{K}^{0.75}$ per d) 1054.6 HP ( $\left.n 4\right)$ and 1124.9 MP $(n 4)$, and heat productions were 772.3 (SE 11.4) HP and 963.4 (SE 23.6) MP $(P<0.01$ ).

Dietary energy restriction resulted in a depressed rate of weight gain at both dietary protein concentrations (Table 3). At a given level of energy intake, weight gain was generally reduced at the lower dietary protein concentration, although at the lowest level of energy intake (group D) there was no statistically significant difference in the rate of weight gain between rats fed on the MP or HP diet. One rat on the low-energy MP diet became anorectic, and had to be removed from the study. Energy restriction at either dietary protein concentration was associated with a fall in the rate of energy deposition and heat production. When rats consuming the MP diet at restricted energy intakes were compared with the ad lib. controls eating the HP diet, heat production was depressed.

At a given dietary protein concentration, rates of protein and fat gain fell with decreasing energy intake (Table 4), so that rats in group D were in negative protein and energy balance. The rate of fat gain was more sensitive to energy restriction than the rate of protein gain, so that at intermediate levels of energy intake on the HP diet, protein gain was coincident with fat loss. This is consistent with previous observations made in the pig (Thorbek, 1975; Fowler et al. 1979) and accords with the findings of Fattet et al. (1984), who indicated that in sheep, protein deposition could be achieved at energy intakes below those required for zero energy balance, provided that protein supply was adequate. At a given feeding level, dietary protein restriction resulted in a depressed rate of protein deposition (groups A, B and C). Rates of fat deposition were elevated in groups A, B and C, although the difference only attained statistical significance in group C. At the lowest level of feeding (group D), dietary protein restriction had no further effect on the rate of protein or fat loss incurred on the HP diet.

The marked changes in body composition which accompany dietary protein restriction 
Table 5. Relation between heat production per unit body protein and fat deposition in rats

(Mean values with their standard errors)

\begin{tabular}{|c|c|c|c|c|c|c|}
\hline \multirow[b]{2}{*}{ Dietary group $\dagger$} & \multirow{2}{*}{$\begin{array}{c}\text { Dietary } \\
\text { protein levelf }\end{array}$} & \multirow[b]{2}{*}{$n$} & \multicolumn{2}{|c|}{$\begin{array}{c}\text { Heat production } \\
(\mathrm{MJ} / \mathrm{kg} \mathrm{BPC} \\
\text { per d) }\end{array}$} & \multicolumn{2}{|c|}{$\begin{array}{c}\text { Fat deposition } \\
\text { (MJ/kg BPC } \\
\text { per d) }\end{array}$} \\
\hline & & & Mean & $\mathrm{SE}$ & Mean & $\mathrm{SE}$ \\
\hline A & $\begin{array}{l}\text { HP } \\
\text { MP }\end{array}$ & $\begin{array}{l}4 \\
4\end{array}$ & $\begin{array}{l}6 \cdot 25 \\
8 \cdot 04^{* *}\end{array}$ & $\begin{array}{l}0.19 \\
0.35\end{array}$ & $\begin{array}{l}1 \cdot 89 \\
2 \cdot 29\end{array}$ & $\begin{array}{l}0 \cdot 10 \\
0 \cdot 13\end{array}$ \\
\hline B & $\begin{array}{l}\text { HP } \\
\text { MP }\end{array}$ & $\begin{array}{l}5 \\
5\end{array}$ & $\begin{array}{l}5 \cdot 57 \\
7 \cdot 13^{* *}\end{array}$ & $\begin{array}{l}0 \cdot 10 \\
0.44\end{array}$ & $\begin{array}{l}0.70 \\
0.96\end{array}$ & $\begin{array}{l}0.05 \\
0 \cdot 22\end{array}$ \\
\hline $\mathrm{C}$ & $\begin{array}{l}\text { HP } \\
\text { MP }\end{array}$ & $\begin{array}{l}5 \\
5\end{array}$ & $\begin{array}{l}5 \cdot 07 \\
5 \cdot 28\end{array}$ & $\begin{array}{l}0 \cdot 16 \\
0.23\end{array}$ & $\begin{array}{r}-0 \cdot 16 \\
0 \cdot 23\end{array}$ & $\begin{array}{l}0 \cdot 15 \\
0 \cdot 14\end{array}$ \\
\hline$D$ & $\begin{array}{l}\text { HP } \\
\text { MP }\end{array}$ & $\begin{array}{l}5 \\
4\end{array}$ & $\begin{array}{l}4.90 \\
4.41\end{array}$ & $\begin{array}{l}0.17 \\
0.30\end{array}$ & $\begin{array}{l}-1 \cdot 14 \\
-0.98\end{array}$ & $\begin{array}{l}0.08 \\
0.09\end{array}$ \\
\hline
\end{tabular}

BPC, average body protein content during the experiment; HP, high protein; MP, marginal protein.

Difference between rats fed on MP or HP diets, within a dietary group, was significant; ${ }^{* *} P<0 \cdot 01$.

† For details, see Table 2.

$\ddagger$ For details, see Table 1 .

raise questions about the adequacy of using body-weight as an experimental variable in contrasting rates of heat production between groups. Indeed, McCracken (1975) questioned 'whether a single function of live weight would be applicable to all protein treatments' and suggested that heat production could alternatively be expressed relative to carcass dry weight. There is also the possibility that the difference in the proportions of fat and lean tissue should be taken into account, although interpretations of relevant studies seem equivocal, and it is often difficult to delineate whether differences in body composition are a cause or effect of differences in metabolic rate and plane of nutrition. On the one hand, there are some studies, both in rats (McCracken \& McNiven, 1983) and sheep (McNiven, 1984), which show that alterations in body fatness induced by feeding are not associated with reductions in the metabolic rate (per unit metabolic body size); this is open to the interpretation that white adipose tissue is a significant contributor to the metabolic rate. On the other hand, it is often considered that with the exception of brown adipose tissue, the most metabolically active tissues are components of the lean body mass (Webster, 1983). Differences in the metabolic rate between lean and fat rats were minimized when expressed on the basis of lean tissue mass (Pullar \& Webster, 1977) as are differences in energy expenditure between men and women (James, 1983), pigs (Sundstol et al. 1974) and sheep (Toutain et al. 1977). Fasting heat production has been found to be highly correlated to the weights of the visceral organs (Koong et al. 1982) and developmental changes in metabolic rate have been attributed to the changing relative organ size making up the lean body mass (Holliday et al. 1967).

In the present circumstances we have chosen to express rates of heat production relative to body protein content as a possible alternative to metabolic body size. In this case, explanations for residual differences in energy expenditure can be sought for either in terms of alterations in the relative sizes of organs contributing to the lean body mass, or alterations in organ metabolic activity or increases in the contribution of adipose tissue, including brown adipose tissue, to the metabolic rate. As shown in Table 5, differences in the rate of heat production were apparent, with elevations on the MP diet in both groups A and B. Moreover, gastrocnemius muscle protein content remains a constant proportion of body- 
weight in rats fed on this diet (results not shown), so that if this muscle is representative of skeletal muscle in general, the contribution of muscle to the lean body mass is increased. Since the metabolic activity of muscle is lower than that of other organs, this should lead, other things being equal, to a decreased rate of heat production rather than the increase observed: this further suggests that metabolic rate was increased on the MP diet. The increased heat production cannot be ascribed to elevated rates of fat deposition: even if all the additional fat was assumed to have been synthesized from carbohydrate with a maximal heat loss of $0.16 \mathrm{~kJ} / \mathrm{kJ}$ deposited (Millward et al. 1976), less than $5 \%$ of the increased heat production could be accounted for. Heat production ( $\mathrm{MJ} / \mathrm{kg}$ body protein content (BPC) per d) was unchanged in groups $C$ and $D$.

These findings accord with those obtained by other workers. Although it has not been usual for results to be expressed relative to the lean body mass, comparisons made on the basis of reasonable assumptions about the body composition of animals fed on low-protein diets suggest that heat production (per $\mathrm{kg} \mathrm{BPC}$ ) is increased when low-protein diets are fed at, or near the levels of energy intake achieved (in $\mathrm{kJ} / \mathrm{d}$ ) in ad lib.-fed controls (Rothwell et al. 1982, 1983; Lunn \& Austin, 1983; Swick \& Gribskov, 1983), and this applies even during force-feeding (McCracken, 1975). The study of McCracken \& McAllister (1984) is difficult to interpret, since although there was no decrease in energetic efficiency of pigs fed on low-protein diets at intakes close to those usually found in pigs consuming normal diets to appetite, the ad lib. intake of pigs on normal diets was not measured simultaneously with that of the experimental group. Body protein deposition was, however, extremely limited, so that heat production relative to control animals with a similar energy intake could have been elevated when expressed on the basis of lean body mass. By contrast, oxygen consumption has been found to be reduced relative to that in well-nourished controls when low protein $(45 \mathrm{~g} / \mathrm{kg}$ diet) feeding is accompanied by a marked reduction in voluntary food intake (Cox et al. 1984), and heat production has been found to be unchanged when animals are pair-fed on low-protein and HP diets (in $\mathrm{kJ} / \mathrm{d}$ ) at levels of energy intake well below those achieved in controls fed to appetite (Fuller, 1983). That low-protein and MP diets result in increased heat production when fed at high, but not at low levels of energy intake, is consistent with the view that dietary-induced thermogenesis occurs in order to dissipate 'excess' energy intake when lean tissue deposition is limited by reductions in dietary protein content (Rothwell et al. 1983). Thus, whilst an explanation for the variability in voluntary intakes of MP diets achieved in different laboratories remains elusive, it would seem that the apparently controversial findings reported by different authors are essentially compatible.

\section{Growth costs}

According to the factorial description of energy balance, energy utilization can be partitioned between factors attributable to maintenance or growth costs. There was a linear relation between MEI ( $\mathrm{kJ} / \mathrm{kg} \mathrm{W}^{0.75}$ per d) and energy deposition (E) $\left(\mathrm{kJ} / \mathrm{kg} \mathrm{W}^{0.75}\right.$ per d) (Fig. 1). Regression analysis indicated the following relations:

$$
\begin{array}{ll}
\text { HP: } \mathrm{MEI}=1.28(\text { SE 0.04) } \mathrm{E}+562, & r 0.99, \\
\text { MP: } \mathrm{MEI}=1.71(\text { SE 0.08) } \mathrm{E}+573, & r 0.98
\end{array}
$$

The overall cost of energy deposition (dMEI/dE or Ee) on the HP diet was at the lower part of the reported range (Millward et al. 1976; Fowler et al. 1979). Ee was elevated on the MP diet $(P<0.001)$ with the maintenance requirement for zero energy balance $\left(M_{e}\right)$ unchanged. The predicted rate of energy loss at zero energy intake is given by $-M_{e} / E e$, and this value was depressed on the MP diet. 


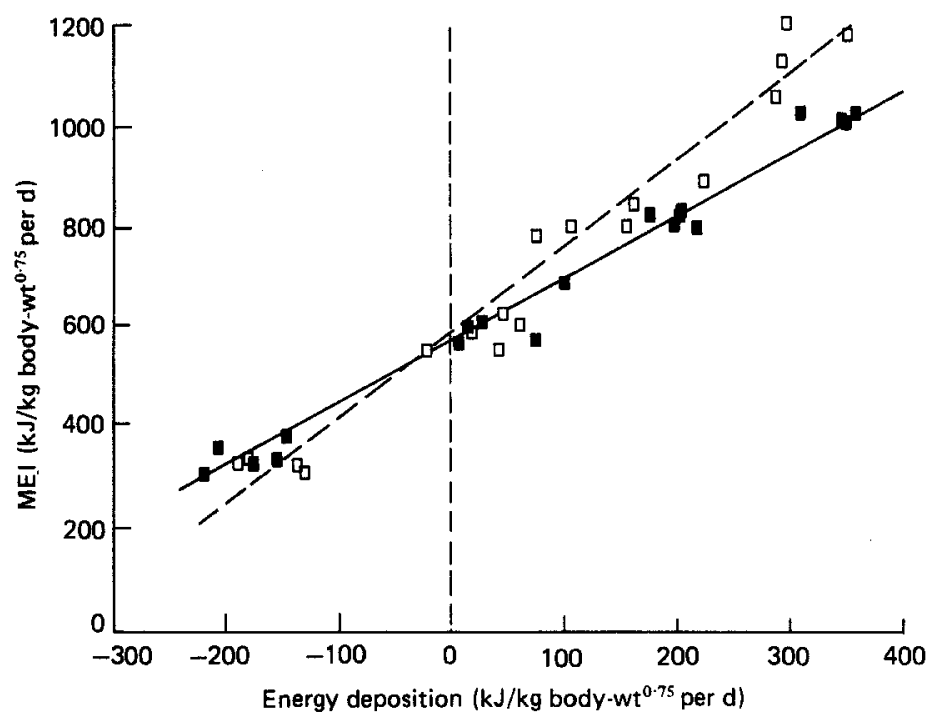

Fig. 1. Relation between metabolizable energy intake (MEI; kJ/kg body-weight ${ }^{0.75}$ per $\mathrm{d}$ ) and energy deposition $\left(\mathrm{kJ} / \mathrm{kg}\right.$ body-weight ${ }^{0.76}$ per $\left.\mathrm{d}\right)$, in rats consuming high ( $\square-\square$ ) or marginal $(\square--\square)$ protein diets.

Ep and Ef can be calculated in accordance with the model proposed by Kielanowski (1966):

$$
\mathrm{MEI}=\mathrm{EpP}+\mathrm{EfF}+\mathrm{M},
$$

where $\mathbf{M}$ (maintenance) is computed as a theoretical estimate of the energy intake for simultaneous zero balance of both protein $(\mathrm{P})$ and fat $(\mathrm{F})$ deposition.

Two approaches to the calculation are possible. Multiple regression can be applied, but the high collinearity of the data obtained in positive protein and fat balance limits the usefulness of this technique. An alternative approach is to adopt a value for either Ep or Ef on external grounds, and to use this to compute the other coefficient and the maintenance value. For this purpose, two values of Ef have been adopted. A maximal value of $1.25 \mathrm{~kJ} /$ $\mathrm{kJ}$ has been assumed, this being within the range of empirically derived values of $\mathrm{Ef}$ reported in mature animals, and in growing animals fed on protein-adequate diets (Agricultural Research Council/Medical Research Council, 1975; Kielanowski, 1976). Lower values of Ef would be anticipated on the basis of the stoichiometry of fat synthesis and, moreover, the value of Ef would vary according to the precursor for fat synthesis. Most efficient is the synthesis of fat from fat (Ef $1.01 \mathrm{~kJ} / \mathrm{kJ})$ and least efficient is the synthesis of dietary fat from protein, assuming conversion via production of glucose, as described in McGilvery (1970). Lindsay (1976) has, however, concluded that most excess protein is metabolized without the intermediate production of glucose, so that on this basis, the energy cost of fat synthesis from protein would be similar to that from carbohydrate $(\mathrm{Ef} 1 \cdot 15 \mathrm{~kJ} / \mathrm{kJ})$. In order to calculate a minimum value of Ef, it was assumed that all the dietary fat (representing $10 \%$ of energy intake) was used for fat synthesis, with the remainder of fat deposition being due to carbohydrate. The value of Ef for individual rats was than calculated as:

$$
\mathrm{Ef}=\left[\mathrm{F}_{1} / \mathrm{F} \times 1.01\right]+1 \cdot 15\left[\left(1-\mathrm{F}_{1} / \mathrm{F}\right)\right] \text {, }
$$

where $F_{1}$ is the energy intake as fat, and $F$ is fat deposition, both expressed as $\mathrm{kJ} / \mathrm{kg} \mathrm{W}^{0.75}$ per $d$. In both cases, irrespective of whether a maximum or minimum value of Ef was adopted, it was assumed that fat breakdown reflects increases in the rate of fat mobilization, 


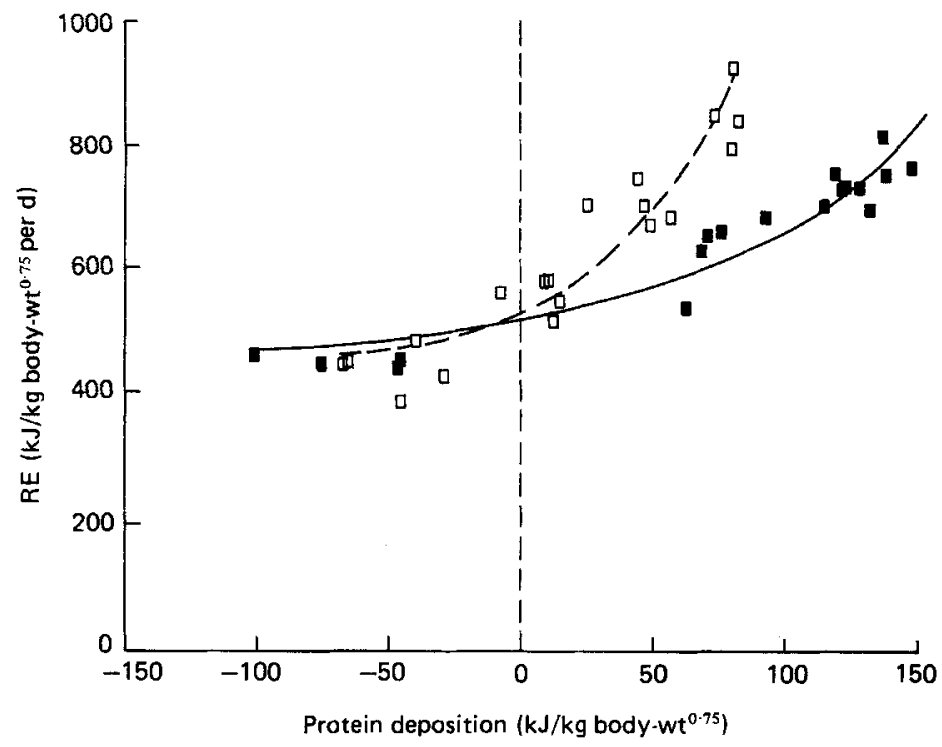

Fig. 2. Relation between the residual energy intake ( $R E, k J / k g$ body-weight ${ }^{0.75}$ per $d$ ) and protein deposition $\left(\mathrm{kJ} / \mathrm{kg}\right.$ body-weight ${ }^{0.75}$ per $\mathrm{d}$ ) in rats consuming high ( $\left.-\square\right)$, or marginal $\left.(\square]--\square\right)$ protein diets. RE calculated as MEI-EfF, where $\mathrm{MEI}$ is metabolizable energy intake, $\mathrm{F}$ is fat deposition (both as $\mathrm{kJ} / \mathrm{kg}$ body-weight ${ }^{0.75}$ per $\mathrm{d}$ ) and $\mathrm{Ef}$ is the energy cost of fat deposition $(1.25 \mathrm{~kJ} / \mathrm{kJ}$ during fat gain, $1 \mathrm{~kJ} / \mathrm{kJ}$ during fat mobilization).

rather than decreases in the rate of fat synthesis (Harris et al. 1984). The value of Ef in negative fat balance was thus taken as $1 \mathrm{~kJ} / \mathrm{kJ}$.

Accordingly, in each case, the energy requirement for fat deposition was subtracted from the MEI and the residual energy (RE) regressed on protein deposition. The plot of RE on protein deposition, assuming a maximum value of Ef, is shown in Fig 2 . The relation was curvilinear, although this primarily reflected the inclusion of data obtained in negative protein balance. When the values obtained in positive protein balance only were used, the solutions for Ep and Ef on the basis of the stated assumptions were:

$$
\begin{aligned}
& \mathrm{HP}: \mathrm{RE}=2 \cdot 1(\mathrm{SE} 0 \cdot 32) \mathrm{P}+469, \quad r 0 \cdot 88 \text {, } \\
& \mathrm{MP}: \mathrm{RE}=4 \cdot 1(\mathrm{SE} 0.53) \mathrm{P}+516, \quad r 0.92 \text {. }
\end{aligned}
$$

where $P$ is protein deposition $\left(\mathrm{kJ} / \mathrm{kg} \mathrm{W}^{0.75}\right.$ per $\left.\mathrm{d}\right)$.

The value for Ep on the HP diet $(2 \cdot 1 \mathrm{~kJ} / \mathrm{kJ})$ was within the range of values reported by other workers (Kielanowski, 1976). On the MP diet, Ep was increased $(4.1 \mathrm{~kJ} / \mathrm{kJ}, P<0.01)$ with no change in the maintenance requirement. When the values obtained in negative protein balance were also included, the slight curvature meant that a quadratic regression model fitted the values better than a linear one, with curvature explaining an additional $6.7 \%$ and $8.5 \%$ of the variance in RE on the HP and MP diets respectively. The resultant equations were:

$$
\begin{aligned}
& \text { HP: } \mathrm{RE}=1 \cdot 15(\text { SE } 0.14) \mathrm{P}+0.005(\mathrm{SE} 0.002) \mathrm{P}^{2}+507, \quad R \quad 0.98 \text {, } \\
& \text { MP: } R E=2 \cdot 72(\text { SE } 0.28) \mathrm{P}+0.015(\text { SE } 0.005) \mathrm{P}^{2}+534, \quad R 0.95 \text {. }
\end{aligned}
$$


At any rate of protein deposition the value of Ep was elevated on the MP diet, but on both diets Ep fell at low rates of protein deposition. This meant that, over the range of mean protein retentions observed, Ep varied between 1.9 and $3.9 \mathrm{~kJ} / \mathrm{kJ}$ on the MP diet. These conclusions were not altered when the minimum value for $\mathrm{Ef}$ was adopted. When the values obtained in positive protein balance only were used, the solutions for Ep and Ef were:

$$
\begin{array}{cc}
\text { HP: } \mathrm{RE}=2.30(\mathrm{SE} 0.28) \mathrm{P}+460, & r 0.92, \\
\mathrm{MP}: \mathrm{RE}=4.52(\mathrm{SE} 0.53) \mathrm{P}+517, & r 0.93 .
\end{array}
$$

The value of Ep was increased on the MP diet $(P<0.01)$. When the values obtained in negative protein balance were also included, a quadratic regression was found to fit the values better than a linear one, with curvature explaining an additional $3.7 \%$ and $5.2 \%$ of the variance in RE on the HP and MP diets respectively. The resultant equations were:

$$
\begin{aligned}
& \text { HP: RE }=1.22\left(\text { SE 0.057) } \mathrm{P}+0.005(\text { SE } 0.0015) \mathrm{P}^{2}+507, \quad r 0.98,\right. \\
& \mathrm{MP}: \mathrm{RE}=2.95(\mathrm{SE} 0.28) \mathrm{P}+0.02(\mathrm{SE} 0.005) \mathrm{P}^{2}+538, \quad r 0.96
\end{aligned}
$$

At any rate of protein deposition, Ep was elevated on the MP diet, but on both diets, Ep fell at low rates of protein deposition.

On both diets, the values of Ee and Ep obtained were, as found in most previous studies, at variance with theoretical estimates (Millward et al. 1976). In the case of Ep, stoichiometric considerations suggest that the energy cost of protein synthesis is around $1.15 \mathrm{~kJ} /$ $\mathrm{kJ}$ (Millward et al. 1976). However, during growth, protein turnover is elevated, particularly in muscle (Millward et al. 1975). Investigations of the relation between whole-body protein synthesis and deposition in the growing pig, indicated that $2.21 \mathrm{~g}$ protein were synthesized for every $1 \mathrm{~g}$ protein deposited (Reeds et al. 1980; Reeds \& Harris, 1980) and our own measurements of whole-body synthesis indicate a value of 2.23 in young rats consuming $\mathrm{HP}$ and MP diets (P. A. Coyer, unpublished results). If this additional protein synthesis is taken into account, a maximum estimate of $\mathrm{Ep}$ is $1.33 \mathrm{~kJ} / \mathrm{kJ}$. Since this is greater than the energy cost of fat synthesis from carbohydrate or protein (Millward et al. 1976), the predicted magnitude of Ee would not be expected to exceed this value. The estimates of Ee and Ep are thus greater than could be accounted for over most of the range of energy and protein gains studied.* That the empirically derived estimates of growth costs exceed the biochemical predictions implies that the statistical associations are confounded by increases in energy expenditure occurring in parallel with increases in growth and food intake, but which are not mechanistically related to changes in the rate of tissue synthesis.

On the MP diet, the value of Ee was increased, whereas previous studies have either failed to demonstrate an effect (McCracken \& Weatherup, 1973; Close et al. 1983) or have reported a tendency (although statistically not significant) for Ee to decrease with reductions in dietary protein content (Walker \& Norton, 1971; Holmes et al. 1979; Fattet et al. 1984). Two of these studies did, however, report increased maintenance costs at low dietary protein concentrations (Walker \& Norton, 1971; Fattet et al. 1984). The extent to which

* Eqn (1) can be rearranged to show that:

$$
E e=(E p-E f) d P / d E+E f .
$$

The relation between protein and energy deposition on the HP diet is given by:

$$
P=0.49 \text { (sE 0.02) E }-0.0007 \text { (SE 0.0001) } \mathrm{E}^{2}+53 \cdot 2 \quad R 0.99 \text {, }
$$

so that $\mathrm{d} P / \mathrm{d} E$ is given by $0.49-0.0014 \mathrm{E}$. Assuming stoichiometric costs of Ep $1 \cdot 33$, Ef 1.15 and Ef 1 during fat mobilization, the predicted value of Ee over the range of energy gains studied attains a minimum of $1 \cdot 12 \mathrm{~kJ} / \mathrm{kJ}$ at zero fat balance (when $\mathrm{E}$ is $92.2 \mathrm{~kJ} / \mathrm{kJ} \mathrm{W}^{0.75}$ per d). Thus even on the HP diet, the observed value of Ep $(1.28 \mathrm{~kJ} / \mathrm{kJ})$ exceeds the theoretical estimate over part of the range studied. 
these studies are directly comparable is, however, limited not only by differences in the age and species of animals used, but also by the actual levels of dietary protein content: the results of Walker \& Norton (1971) indicate that the overall thermogenic response to dietary protein concentration may be parabolic, with heat production attaining a minimum at intermediate levels of dietary protein content.

The finding that Ep was elevated on the MP diet is superficially in agreement with the conclusion drawn by Campbell \& Dunkin (1983), but the interpretation of their study is limited by analytical errors and by the fact that levels of dietary protein content were not compared in the same experiment. Close et al. (1983) found that when Ep and Ef were calculated by multiple linear regression, Ep was elevated and Ef was depressed with dietary protein restriction, but the values were highly collinear. When Ef was held constant at $1.16 \mathrm{~kJ} / \mathrm{kJ}$, it was concluded that Ef was unaffected by dietary protein concentration. It seems likely that the high value of Ep in the present study reflects an attempt to dissipate 'excess' energy intake as heat on the MP diet, and this may involve catecholamine-mediated increases in brown adipose tissue thermogenesis (Rothwell et al. 1983; Rothwell \& Stock, 1984). The absence of effect in the study conducted by Close et al. (1983) may thus reflect a decreased thermogenic responsiveness in older pigs (Gurr et al. 1980), coupled with an insensitivity of the relation between protein deposition and energy intake to dietary protein content, at the rather high range of dietary protein concentrations used (18-29\% of GE as protein).

The demonstrated variability of growth costs with nutritional manipulation emphasizes the circularity of approaches still current in the analysis of energy expenditure. Although several authors have stressed the statistical limitations of these values (Kielanowski, 1966; Holmes et al. 1979; Close et al. 1983), they are frequently treated as physiological constants, used to delineate the extent to which alterations in the rate of heat production can be ascribed to changes in body-weight or changes in the rate and composition of growth. Growth costs have been assumed constant irrespective of nutritional or hormonal status, age or phenotype, by us (Coyer et al. 1984, 1985b) and others (Pullar \& Webster, 1977; McCracken \& McAllister, 1984, Roberts \& Coward, 1984). The constancy of growth costs is a component of arguments for adaptation to low-energy intakes (Mohan \& Narasinga Rao, 1983) and for (Rothwell \& Stock, 1983) and against (Hervey \& Tobin, 1982) luxus konsumption. The present results emphasize that both maintenance and growth costs are potentially variable and indeed the consistency of reported growth costs masks a wide range of assumptions about the relation between maintenance and body size (Kielanowski \& Kotarbinska, 1970; Schiemann, 1970; Pullar \& Webster 1974, 1977; Thorbek, 1975). At any event, the factorial partitioning of changes in expenditure into factors associated with body-weight and net growth costs cannot explain the biochemical mechanisms involved; on the contrary, arguments based on such analysis (e.g. Lunn \& Sawaya, 1985) may mean that physiologically significant changes in heat production are overlooked. The factorial analysis of heat production will nevertheless continue to find a role in the description of energy requirements for growing animals. In this context, the present results demonstrate that, under the defined conditions of our experiments, heat production is elevated in rats consuming MP diets fed ad lib.: this reflects an increase in the energy costs of growth.

This work was supported by a London University Sanderson Wells studentship awarded to P.A.C. The authors are grateful to Mrs E. Hoinville for reading and commenting upon the statistical analyses, and to Mr Mike Elston for helpful discussion. Mr Peter Donachie provided technical assistance. 


\section{REFERENCES}

Agricultural Research Council/Medical Research Council (1975). Food and Nutrition Research, p. 30. London: H.M.S.O.

Agricultural Research Council (1981). The Nutritional Requirements of Pigs. Slough : Commonwealth Agricultural Bureaux.

Armitage, P. (1971). Statistical Methods in Medical Research. Oxford and Edinburgh: Blackwell Scientific Publications.

Bailey, N. T. C. (1981). Statistical Methods in Biology, 2nd ed. London: Hodder and Stoughton.

Campbell, R. G. \& Dunkin, A. C. (1983). British Journal of Nutrition 49, 221-230.

Close, W. H., Bershauer, F. \& Heavens, R. P. (1983). British Journal of Nutrition 49, 255-269.

Cox, M. D., Dalal, S. S., Heard, C. R. C. \& Millward, D. J. (1984). Journal of Nutrition 114, 1609-1616.

Coyer, P. A., Cox, M., Rivers, J. P. W. \& Millward, D. J. (1984). Proceedings of the Nutrition Society 43, $75 \mathrm{~A}$.

Coyer, P. A., Rivers, J. P. W. \& Millward, D. J. (1985a). Proceedings of the Nutrition Society 44, 131 A.

Coyer, P. A., Rivers, J. P. W. \& Millward, D. J. (1985 b). British Journal of Nutrition 53, 491-499.

Coyer, P. A., Donachie, P. D., Bates, P. C., Rivers, J. P. W. \& Millward, D. J. (1986). Proceedings of the Nutrition Society 45, 108A.

Fattet, I., Hovell, F. D. Deb, Ørskov, E. R., Kyle, D. J., Pennie, K. \& Smart, R. I. (1984). British Journal of Nutrition 52, 561-574.

Food and Agriculture Organization/World Health Organization/United Nations University (1985). Technical Report Series no. 724. Geneva: WHO.

Fowler, V. R., Fuller, M. F., Close, W. H. \& Whittemore, C. T. (1979). In Energy Metabolism, European Association for Animal Production Publication no. 26, pp. 151-157 [L. E. Mount, editor]. London: Butterworths.

Fuller, M. F. (1983). Journal of Nutrition 113, 15 20.

Gurr, M. I., Mawson, R., Rothwell, N. J. \& Stock, M. J. (1980). Journal of Nutrition 110, 532-542.

Harris, P. M., Hodgson, D. F. \& Broadhurst, R. B. (1984). British Journal of Nutrition 52, 289-306.

Hervey, G. R. \& Tobin, G. (1982). Proceedings of the Nutrition Society 41, 137-153.

Holliday, M. A., Potter, D., Jarrah, A. \& Beargh, S. (1967). Pediatric Research 1, 185-195.

Holmes, C. W., Christensen, R. Carr, J. R. \& Pearson, G. (1979). In Energy Metabolism, European Association for Animal Production Publication no. 26, pp. 97-100 [L. E. Mount, editor]. London: Butterworths.

James, W. P. T. (1983). Lancet ii, 386-389.

Kielanowski, J. (1966). Animal Production 8, 121-128.

Kielanowski, J. (1976). In Protein Metabolism and Nutrition, European Association for Animal Production Publication no. 16, pp. $207-214$ [D. J. A. Cole, K. N. Borrman, P. J. Buttery, D. Lewis, R. J. Neale and H. Swan, editors]. London: Butterworths.

Kielanowski, J. \& Kotarbinska, M. (1970). In Energy Metabolism of Farm Animals, European Association for Animal Production Publication no. 13, pp. 145-148 [A Schürch and C. Wenk, editors]. Zurich: Juris Druck and Verlag.

Kleiber, M. (1975). The Fire of Life, p. 268. New York: Kreiger.

Koong, L.-J., Neinaber, J. A., Pekas, J. C. \& Yen, J.-T. (1982). Journal of Nutrition 112, 1638-1642.

Lindsay, D. B. (1976). In Protein Metabolism and Nutrition, European Association for Animal Production Publication no. 16, pp. 183-195 [D. J. A. Cole, K. N. Boorman, P. J. Buttery, D. Lewis, R. J. Neale and H. Swan, editors]. London: Butterworths.

Lunn, P. G. \& Austin, S. (1983). Journal of Nutrition 113, 1791-1802.

Lunn, P. G. \& Sawaya, A. L. (1985). British Journal of Nutrition 54, 322.

McCracken, K. J. (1975). British Journal of Nutrition 33, 277-289.

McCracken, K. J. \& Gray, R. (1976). Proceedings of the Nutrition Society 35, 59 A.

McCracken, K. J. \& McAllister, A. (1984). British Journal of Nutrition 51, 225-234.

McCracken, K. J. \& McNiven, M. A. (1983). British Journal of Nutrition 49, 193-202.

McCracken, K. J. \& Weatherup, S. T. C. (1973). Proceedings of the Nutrition Society 32, 66A.

McGilvery, R. W. (1970). Biochemistry: a Functional Approach. Philadelphia: W. B. Saunders.

McNiven, M. A. (1984). British Journal of Nutrition 51, 297-304.

Miller, D. S. \& Payne, P. R. (1959). British Journal of Nutrition 13, 501-508.

Miller, D. S. \& Payne, P. R. (1962). Journal of Nutrition 78, 255-262.

Millward, D. J., Garlick, P. J., Stewart, R. J. C., Nnanyelugo, D. O. \& Waterlow, J. C. (1975). Biochemical Journal 150, 235-243.

Millward, D. J., Garlick, P. J. \& Reeds, P. J. (1976). Proceedings of the Nutrition Society 35, 339-349.

Mohan, P. F. \& Narasinga Rao, B. S. (1983). Journal of Nutrition 113, 79-85.

Puller, J. D. \& Webster, A. J. F. (1974). British Journal of Nutrition 31, 377-392.

Pullar, J. D. \& Webster, A. J. F. (1977). British Journal of Nutrition 37, 355-363. 
Reeds, P. J., Fuller, M. J., Cadenhead, A., Lobley, G. E. \& McDonald, J. D. (1980). British Journal of Nutrition 43, 445-455.

Reeds, P. J. \& Harris, C. I. (1980). In Nitrogen Metabolism in Man, pp. 391-408 [J. C. Waterlow and J. M. L. Stephen, editors]. London: Applied Science Publishers.

Roberts, S. \& Coward, A. (1984). Journal of Nutrition 114, 2193-2200.

Rothwell, N. J. \& Stock, M. J. (1983). Brown Adipose Tissue, Recent Advances in Physiology, vol. 10, p. 372. Edinburgh: Churchill Livingstone.

Rothwell, N. J., Stock, M. J. \& Tyzbir, R. S. (1982). Journal of Nutrition 112, 1663-1672.

Rothwell, N. J., Stock, M. J. \& Tyzbir, R. S. (1983). Metabolism 32, 257-261.

Sawaya, A. L. \& Lunn, P. G. (1985). British Journal of Nutrition 53, 175-181.

Schiemann, R. (1970). Mathematitisch-Naturrwissenschafiche Reine 19, 35-40.

Sundstol, F., Ekern, A. \& Haugen A. E. (1974). In Energy Metabolism of Farm Animals, European Association for Animal Production Publication no. 14, pp. 249-251 [K. H. Menke, H. J. Lantzsch and J. R. Reichl, editors]. Hohenheim: University of Hohenheim.

Swick, R. W. \& Gribskov, C. J. (1983). Journal of Nutrition 113, 2289-2294.

Thorbek, G. (1975). Studies on Energy Metabolism in Growing Pigs 424. Copenhagen: Beretning fra Statens Husdryrbrugs forsog.

Toutain, P.-L., Toutain, C., Webster, A. J. F. \& McDonald J. D. (1977). British Journal of Nutrition 38, 445454.

Tulp, O., Krupp, P. P., Danforth, E. \& Horton, E. S. (1979). Journal of Nutrition 109, 1321-1332.

Walker, D. M. \& Norton, B. W. (1971). Journal of Agricultural Science, Cambridge 77, 363-369.

Webster, A. J. F. (1983). Mammalian Thermogenesis, p. 193. London: Chapman and Hall. 